\title{
Kekuatan Mengikat Surat Penunjukan Penyedia Barang dan Jasa Pemerintah dalam Kontrak Pengadaan Barang/Jasa Pemerintah di Masa Pandemi Covid-19
}

\author{
Merry Tjoanda \\ Fakultas Hukum Universitas Pattimura, Ambon, Indonesia \\ E-mail: tjoanda.merry@gmail.com
}

\begin{tabular}{l}
\multicolumn{1}{c}{ Dikirim: $28 / 05 / 2020$} \\
\hline Info Artikel \\
\hline Keywords: \\
SPPBJ Binding \\
Strength; Goods / \\
Services Procurement \\
Contracts; Impact of \\
the Pandemic; covid- \\
19. \\
\\
Pandemi; covid-19. \\
Barang/Jasa; Dampak \\
Kekuatan Mengikat \\
SPPB; Kontrak \\
Kata Kunci: \\
\hline
\end{tabular}

\section{Abstract}

The process of determining the auction winner for a goods / services procurement project ends with the issuance of SPPBJ by PPK. The purpose of this study is to analyze the legally binding force of the Goods / Services Provider Appointment Letter (SPPBJ) in government procurement contracts of goods / services, especially during the Covid19 pandemic. The results showed that before the contract for the procurement of goods / services was signed by the PPK and the provision of goods / services, the SPPBJ that had been issued by the function of executing the auctioned work provided that there were no objections from other participants and the rebuttal period had ended. SPPBJ acts as a binding contract, where SPPBJ is very much needed because the contract may be canceled or transferred due to refocusing of activities and relocation of budgets due to the impact of the Covid-19 pandemic as it is today. There needs to be a more stringent regulation in the SPPBJ issuance process to deal with irregularities that may still occur, which is carried out by PPK.

\begin{tabular}{l}
\hline Abstrak \\
\hline Proses penentuan pemenang lelang suatu proyek pengadaan barang/jasa \\
diakhiri dengan penerbitan SPPBJ oleh PPK. Tujuan dari penelitian ini \\
untuk menganalisis kekuatan hukum mengikat dari Surat Penunjukan \\
Penyedia Barang/Jasa (SPPBJ) dalam kontrak pengadaan barang/jasa \\
pemerintah, khususnya di masa pandemi Covid-19. Hasil penelitian \\
menunjukan bahwa sebelum kontrak pengadaan barang/jasa \\
ditandatangani oleh PPK dan penyedian barang/jasa, SPPBJ yang telah \\
diterbitkan oleh berfungsi sebagai pelaksana pekerjaan yang dilelangkan \\
dengan catatan tidak ada sanggahan dari perserta lain dan masa sanggah \\
telah berakhir. SPPBJ berlaku sebagai kontrak pengikat, dimana SPPBJ \\
sangat diperlukan karena dapat saja kontrak dibatalkan atau dialihkan \\
karena adanya refocusing kegiatan dan relokasi anggaran akibat dampak \\
pandemi Covid-19 seperti saat ini. Perlu ada pengaturan yang lebih ketat \\
dalam proses penerbitan SPPBJ untuk mengatasi penyimpangan-
\end{tabular}




\section{A. PENDAHULUAN}

Masa tanggap darurat saat bencana alam (seperti pandemic Covid-19) merupakan salah satu faktor yang berpotensi meningkatkan resiko korupsi dalam proses pengadaan barang dan jasa pemerintah. ${ }^{1}$ Korupsi pengadaan barang dan jasa adalah yang paling lumrah dan mudah. Korupsi tipe ini masih konvensional. Bukan yang benar-benar canggih, dalam hal ini dilakukan dengan cara seperti penggelembungan harga (markup), penyalahgunaan kewenangan. ${ }^{2}$

Kasus korupsi yang terjadi dalam proses pengadaan barang/jasa, baik yang melibatkan pihak pemerintah maupun pihak swasta, baik yang mengenai kebocoran yang terjadi, inefisiensi maupun ketidaktransparanan proses pengadaan barang/jasa yang membawa dampal persaingan tidak sehat yang mana pada akhirnya bermuara pada hasil yang tidak dapat dipertanggungkjawabkan dari segi fisik, keuangannya maupun manfaatnya bagi kelancarann tugas pemerintah dan pelayanan yang optimal kepada masyarakat.

Berbagai upaya pemerintah lakukan guna mencegah maupun meminimalisir kebocoran keuangan maupun pelaksanaan pengadaan barang/jasa Pemerintah, dimulai dari Keputusan Presiden Nomor 18 Tahun 2000 sampai dengan terakhir dikeluarkan Peraturan Presiden Nomor 16 Tahun 2018 tentang Pengadaan Barang/Jasa Pemerintah (Perpres No. 16 Tahun 2018) untuk menggantikan Peraturan Presiden Nomor 54 Tahun 2010 beserta peraturan-peraturan perubahannya.

Ketika pemerintah bertindak dalam lapangan keperdataan dan tunduk pada peraturan hukum perdata, maka pemerintah bertindak sebagai wakil dari badan hukum bukan wakil dari jabatan, sehingga tindakan pemerintah tersebut adalah tindakan badan hukum ${ }^{3}$, salah satu perbuatan hukum pemerintah di bidang hukum privat adalah melaksanakan Kontrak Pengadaan Barang/Jasa Pemerintah khususnya Kontrak Kerja Konstruksi untuk memenuhi kebutuhan infrastruktur pelayanan publik ${ }^{4}$.

Pemerintah dalam kegiatan memenuhi kebutuhan barang dan jasa, melaksanakan kontrak pengadaan barang/jasa yang melibatkan penyedia barang/jasa. Penyedia barang/jasa ditentukan melalui proses pelelangan yang dilanjutkan dengan penandatangan kontrak antara PPK dengan penyedia barang/jasa. Proses pengadaan/barang jasa melalui penyedia barang/jasa telah diatur dalam Perpres Pengadaan Barang/Jasa Pemerintah yang secara garis besar dibagi menjadi tiga tahapan yaitu persiapan, pelaksanaan pemilihan penyedia serta penandatanganan dan pelaksanaan kontrak. ${ }^{5}$

Kegiatan Pengadaan barang dan jasa pada hakikatnya merupakan upaya pihak pemerintah untuk mendapatkan kebutuhannya baik berupa barang, jasa maupun

1 Listiyanto, A. (2012), "Pembaharuan Regulasi Pengadaan Barang dan Jasa Pemerintah", Rechts Vinding, 1 (1): 113-134, h. 121.

2 Butarbutar, R. (2015), "Pertanggungjawaban Korporasi Dalam Tindak Pidana Korupsi Pengadaan Barang dan Jasa Pemerintah di Bidang Konstruksi”, Jurnal Penelitian Hukum Legalitas, 9 (1): 51-55, h. 52.

3 Kuahaty, S. S. (2011), "Pemerintah Sebagai Subjek Hukum Perdata Dalam Kontrak Pengadaan Barang Atau Jasa", SASI, 17 (3): 53-58, h. 53.

4 Manery, B. D. (2017), "Makna Dan Fungsi Itikad Baik Dalam Kontrak Kerja Konstruksi”, SASI, 23 (2): 136-148, h. 137.

5 Fajarini, D. P. (2019). "Subkontrak Dalam Pengadaan Barang/Jasa Pemerintah", Mimbar Keadilan, 12 (1): 67-84, h. 73. 
pembangunan infrasturktur. Pengadaan dapat dilakukan dengan dua cara, yaitu melalui penyedia atau swakelola 6 , yang secara otomatis akan terlibat dalam kontraktual dengan penyedia jasa. Kontraktualisasi (contractualization), yakni pemanfaatan kontrak sebagai instrumen dalam menjalankan fungsi pemerintahan.

Kontrak pengadaan barang/jasa, terdapat beberapa tahapan di dalamnya, yaitu tahap pembentukan (pra kontrak), tahap kontrak (penandatanganan) dan pelaksanaan (pasca kontrak), pada tahapan kontraktual dan tahapan post kontraktual, kebebasan berkontrak hanya merupakan pelaksanaan dari ketentuan undang-undang, ${ }^{7}$ tetapi pada dasarnya, perjanjian pengadaan barang dan jasa dalam pembuatannya tetap mengikuti apa yang telah ada dalam Burgerlijk Wetboek. Contohnya dalam perjanjian pengadaan barang dan jasa, keabsahan menjadi hal yang penting dalam pembuatan perjanjian tersebut. Keabsahan dalam hal ini tetap mengikuti apa yang ada pada Pasal 1320 Burgerlijk Wetboek. $^{8}$

Tahapan atau prosedur pemelihan penyedia barang merupakan langkah-langkah yang harus ditempuh dalam pemelihan penyedia barang/jasa.prosedur ini disesuaikan dengan metode dalam pemilihan penyedia barang/jasa yang terdiri dari; Pelelangan umum, Pelelangan terbatas, Pemilihan langsung, dan, Penunjukan langsung. ${ }^{9}$

Proses yang penting dalam tahapan pra kontrak sesudah pengumuman lelang adalah pemilihan penyedia barang/jasa. Kelompok Kerja Unit Layanan Pengadaan (Pokja ULP)/Pejabat pengadaan dalam melaksanakan pemilihan penyedia barang/jasa, harus terlebih dahulu menetapkan metode pemilihan penyedia barang dan jasa, metode penyampaian dokumen, metode evaluasi penawaran, metode penilaian kualifikasi dan jenis kontrak yang paling sesuai dengan pengadaan barang dan jasa yang bersangkutan. ${ }^{10}$

Pada proses evaluasi penawaran merupakan tahap akhir dari keseluruhan proses lelang sebelum akhirnya dilakukan penetapan pemenang lelang oleh Pokja ULP/Pejabat Pengadaan. Setelah Pokja ULP/Pejabat Pengadaan menetapkan pemenang lelang maka paling lambat 6 hari sejak penetapan pemenang lelang tersebut Pejabat Pembuat Komitmen (disingkat PPK) berkewajiban untuk menerbitkan Surat Penunjukan Penyedia Barang/Jasa (disingkat SPPBJ). SPPBJ berfungsi sebagai pelaksana pekerjaan yang dilelangkan dengan catatan tidak ada sanggahan dari perserta lain dan masa sanggah telah berakhir.

PPK dalam menerbitkan SPPBJ, seharusnya sudah mempelajari dan memahami keseluruhan Berita Acara Hasil Pelelangan (disingkat BAHP) yang dibuat oleh Pokja ULP/pejabat pengadaan. BAHP merupakan laporan lengkap terkait proses pemilihan penyedia dengan output akhir adalah penetapan pemenang yang lolos dalam masa sanggah atau sanggah banding. ${ }^{11}$

BAHP sendiri setidaknya harus berisikan beberapa unsur pokok, yaitu:

6 Situmeang, I. S. (2017), "Pembatalan Surat Penunjukan Penyedia Barang dan Jasa dalam Kontrak Pengadaan Barang dan Jasa Pemerintah", DiH Jurnal Ilmu Hukum, 13 (26): 217-230, h. 217.

7 Muskibah dan Hidayah, L. N. (2020), "Penerapan Prinsip Kebebasan Berkontrak dalam Kontrak Standar Pengadaan Barang dan Jasa Pemerintah di Indonesia", Refleksi Hukum, 4 (2): 175-194, DOI: https://doi.org/10.24246/jrh.2020.v4.i2.p175-194, h, 175

8 Putra, K. D. H. (2019), "Penyelesaian Sengketa Kontrak dalam Pengadaan Barang/Jasa Pemerintah", Jurist-Diction, 2 (4): 1303-1318, h. 1304.

9 Sanjaya, D; Siregar, R; Windha. (2013), “Analisis Yuridis Pengadaan Barang/Jasa yang Dilakukan Dinas Pendidikan Kota Tanjungbalai Ditinjau dari Peraturan Presiden Nomor 54 Tahun 2010 Tentang Pengadaan Barang/Jasa Pemerintah", TRANSPARENCY Jurnal Hukum Ekonomi, 1 (2): 1-7, h. 5.

10 Simamora, Y. S. (2013). Hukum Kontrak (Kontrak Pengadaan barang dan Jasa Pemerintah di Indonesia), Surabaya: Laksbang, h. 41.

11 Ramli, S. (2014). Bacaan Wajib Sertifikasi Ahli Pengadan Barang/Jasa Pemerintah, Jakarta: Visimedia, h. 158. 
1) nama seluruh peserta;

2) harga penawaran atau harga penawaran terkoreksi, dari masing-masing peserta;

3) metode evaluasi yang digunakan;

4) unsur-unsur yang dievaluasi;

5) rumus yang dipergunakan;

6) keterangan-keterangan lain yang diaanggap perlu mengenai hal ikhwal pelaksanaan pelelangan;

7) jumlah peserta yang lulus dan tidak lulus pada setiap tahapan evaluasi; dan

8) tanggal dibuatnya berita acara;

Memasuki tahun 2020, muncul virus yang mewabah yang meliputi seluruh negara di dunia, di mana lebih dari 212 negara terpapar wabah Corona Virus Diseases 2019 (Covid19). Virus ini sendiri mulai muncul pertama kali di kota Wuhan pada akhir tahun 2019, yang dalam perkembangannya kurang dari dua bulkan sangat laju penyebarannya, sehingga World Health Organization (WHO) menetapkan sebagai pandemi. Di Indonesia, Covid-19 telah mewabah di seluruh provinsi, bahjkan beberapa provinsi dinyatakan sebagai zona merah, karena sangat pesat penyebarannya dan telah berdampak pada banyaknya korban jiwa.

Kondisi pandemi Covid-19 mendapat perhatian serius pemerintah melalui berbagai upaya untuk mencegah, mengatasi dan menekan penyebaran Covid-19, dalam kondisi demikian sangat berpengaruh terhadap pelaksanaan pemerintahan, khususnya pembangunan secara nasional. Pelaksanaan pembangunan harus mengalami penundaan bahkan penghentian sementara. Pekerjaan yang sudah berjalan, tidak dapat dilanjutkan secara optimal dan harus dihentikan.

Kondisi Covid-19 tentu akan berdampak pula pada pelaksanaan kontrak pengadaan barang jasa, karena upaya mengatasi dan menekan laju penyebaran Covid-19 lebih mendapat prioritas. Banyak proyek yang telah melalui proses pelelangan dan telah ditentukan pemenang lelang, bahkan telah diterbitkan Surat Penunjukan Penyedia Barang/Jasa (disingkat SPPBJ) yang kemudian dilanjutkan dengan proses finalisasi kontrak pengadaan barang/jasa untuk ditindaklanjuti dengan penandatanganan kontrak dan pelaksanaan pekerjaan menjadi batal. Pembatalan SPPBJ setidaknya akan menimbulkan masalah hukum tersendiri dalam pelaksanaan kontrak barang/jasa karena akan timbul kerugian, baik pada pihak pemerintah, tetapi juga pada pihak penyedia barang/jasa, untuk itu perlu dikaji tentang kekuatan mengikat SPPBJ dalam keadaan kahar seperti pandemic Covid-19 yang saat ini terjadi.

\section{B. PEMBAHASAN}

\section{Tugas dan Kewenangan Pejabat Pembuat Komitmen dalam Menerbitkan Surat Penunjukan Penyedia Barang/Jasa}

Pengaturan pengadaan barang dan jasa pemerintah maka diperlukan pengaturan hukum yang jelas dan mampu memenuhi perkembangan pasar, sehingga prinsip kepastian hukum diperoleh oleh para pihak yang terlibat dalam proses pengadaan tersebut. Pengadaan barang dan jasa pemerintah baik berdasarkan hukum nasional maupun hukum internasional harus berdasarkan persaingan sehat, transparansi, efisiensi dan nondiskriminasi. ${ }^{12}$

12 Pane, M. D. (2017), “Aspek Hukum Pengadaan Barang Dan Jasa Pemerintah Suatu Tinjauan Yuridis Peraturan Pengadaan Barang Dan Jasa Pemerintah”, Jurnal Media Hukum, 24 (2): 174-155, DOI: 10.18196/ jmh.2017.0090.147- 155, h. 150 
PPK dalam hukum pengadaan barang/jasa sebagaimana diatur dalam Pasal 1 angka 10 Perpres No.16 Tahun 2018adalah pejabat yang mendapat kewenangan dari Pengguna Anggaran (PA)/Kuasa Pengguna Anggaran (KPA) untuk membuat keputusan dan/atau melakukan tindakan yang dapat berakibat pada pengeluaran anggaran belanja negara/anggaran belanja daerah.

Pelaksanaan kegiatan pengadaan barang/jasa pemerintah sepenuhnya didasarkan pada adanya kontrak/perjanjian antara pemeritah sebagai pengguna barang/jasa dengan penyedia barang/jasa. Kontrak/perjanjuian pengadaan barang/jasa merupakan kegiatan yang membutuhkan banyak pemahaman dan kemampuan, yang dimulai dari perencanaan pengadaan sampai selesainya pekerjaan yang terdiri dari tahapan perencanaan pengadaan, pelaksanaan pengadaan/pekerjaan dan pengendalian, penandatangan kontrak/perjanjian, dan melaporkan dan menyerahkan hasil pekerjaan.

Secara administratif dalam kontrak/perjanjian pengadaan barang/jasa pemerintah, PPK bertanggung jawab penuh terhadap teknis dan finansial pengadaan barang/jasa. PPK bertindak mewakili intansi pemerintah (Kementerian/Lembaga/Perangkat Daerah disingkat $\mathrm{K} / \mathrm{L} / \mathrm{PD}$ ) dalam membuat kontrak/perjanjian dengan pihak lain selaku penyedia barang/jasa.

K/L/PD tidak akan dapat melakukan kontrak/perjanjian tanpa adanya PPK. Hal ini menunjukan pada kedudukan penting PPK dalam pengadaan barang/jasa pemerintah. Berhasil atau tidak berhasilnya suatu proses pengadaan barang/jasa pada K/L/PD sangat tergantung pada PPK. Ini berarti bahwa tugas pokok PPK berkaitan erat dengan penggunaan anggaran negara dan/atas anggaran daerah atau pengelolaan keuangan, karena itu dalam pelaksanaannya menuntut suatu keahlian dan ketelitian serta tanggung jawab yang berbeda dengan tugas pokok seorang pegawai administrasi lainnya. Kesalahan yang dilakukan PPK dalam pelaksanaan tugasnya akan berakibat timbulnya kerugian negara yang berujung pada tuntutan ganti rugi atau tuntutan lainnya.

Pergantian Peraturan Presiden Nomor 54 Tahun 2010 tentang Pengadaan Barang Jasa Pemerintah (disingkat Perpres No. 54 Tahun 2010) dengan dikeluarkannya Peraturan Presiden Nomor 16 Tahun 2018 tentang Pengadaan Barang/Jasa Pemerintah (disingkat Perpres No. 16 Tahun 2018) mengatur pada Pasal 8 Perpres No. 16 Tahun2018 tentang pelaku pengadaan barang/jasa pemerintah terdiri dari PA, KPA, PPK, Pejabat Pengadaan, Kelompok Kerja Pemilihan (disingjat Pokja Pemilihan), Agen Pengadaan, Pejabat Penerima Hasil Perkerjaan (disingkat PjPHP), Panitia Penerima Hasil Pekerjaan (disingkat PPHP), Penyelenggara Swakelola, dan Penyedia.

Selain itu, pergantian Perpres No. 54 Tahun 2010 dengan Perpres No. 16 Tahun 2018 berakibat pada adanya perubahan tugas PPK. Untuk itu perlu dijelaskan mengenai tugas pokok dan wewenang PPK sesuai dengan pengaturtan dalam Perpres No. 16 Tahun 2018. Tugas pokok PPK dalam Perpres No. 16 Tahun 2018, terdapat dalam ketentuan Pasal 11. Berdasarkan ketentuan Pasal 11 Perpres No. 16 Tahun 2018 maka dapat dikemukakan bahwa tugas PPK adalah sebagai berikut;

a) menyusun perencanaan pengadaan barang/jasa yang di dalamnya meliputi penyusunan spesifikasi, HPS dan rancangan kontrak/perjanjian;

b) menetapkan tim pendukung seperti tenaga administrasi, direksi lapangan, direksi teknis;

c) menetapkan tim atau tenaga ahli yaitu tim atau orang yang kompeten dan melaporkan pelaksanaan dan penyelesaian kegiatan kepada PA/ KPA, untuk Prepres No. 16 Tahun 2018 serah terima dengan penyedia dilakukan oleh PPK ( bukan oleh PPHP lagi), maka PPK dapat melakukan sendiri, atau dibantu tim pendukung, tim atau tenaga ahli dan atau konsultan pengawas; 
d) melaksanakan E-purchasing, dimana PPK dapat langsung melakukan transaksi terhadap produk-produk katalaog. PPK dapat melakukan sendiri e-purchasing, sedangkan nilai proyek sampai dengan Rp 200.000.000 dilakukan oleh pejabat pengadaan;

e) menilai kinerja penyedia barang/jasa yaitu menilai pelaksanaan kontrak/perjanjian oleh penyedia bafrang/jasa;

f) PPK dalam melaksanakan tugasnya dapat dibantu oleh pengelola pengadaan barang/jasa, artinya dapat dibantu oleh jabatan fungsional pengadaan.

Sebagaimana telah dikemukakan di atas bahwa PA/KPA berwenang dalam menetapkan PPK. Penetapan PPK berakibat pada terjadinya pendelegasian kewenangan dari PA/KPA kepada PPK. Pengaturan ini terdapat dalam ketentuan Pasal 9 ayat (1) huruf g Perpres No. 16 Tahun 2108. Dengan kewenangan dari PA/KPA, PPK memiliki kewenangan untuk menandatangani kontrak/perjanjian. Dalam hal tidak ada personel yang dapat ditunjuk, KPA dapat merangkap sebagai PPK.

PPK dalam tahap awal sebelum pelaksanaan pengadaan barang/jasa dilakukan, dapat mengundang Unit Kerja Pengadaan Barang/Jasa (disingkat UKPBJ) atau pejabat pengadaan dan tim teknis untuk melakukan pengkajian ulang terhadap Rencana Umum Pengadaan yang telah ditetapkan oleh PA/KPA dalam rapat koordinasi awal.

Unit Layanan Pengadaan (disingkat ULP)/Panitia Lelang menyampaikan BAHP kepada PPK sebagai dasar untuk menerbitkan SPPBJ. PPK dapat menerbitkan SPPBJ dengan berlandaskan pada ketentuan bahwa tidak ada sanggahan dari peserta lelang, maupun sanggahan banding. Walaupun ketentuan penerbitan SPPBJ telah dipersiapkan secara matang oleh ULP/panitia pengadaan, sebaiknya PPK meneliti ulang BAHP yang diserahkan oleh ULP/Panitia Pengadaan.

Setelah PPK menerbitkan SPPBJ, PPK masih harus melakukan finalisasi terhadap rancangan kontrak/perjanjian, dan menandatangani kontrak/perjanjian pelaksanaan pekerjaan, apabila dananya cukup tersedia dalam dokumen anggaran, dengan ketentuan:

a) Penandatangan kontrak/perjanjian dilakukan paling lambat 14 hari (empat belas) hari kerja setelah diterbitkan SPPBJ, dan setelah penyedia menyerahkan jaminan pelaksanaan dengan ketentuan:

1) Nilai jaminan pelaksanaan untuk harga penawaran terkoreksi $80 \%$ (delapan puluh perseratus) sampai dengan $100 \%$ (seratus persen) nilai total HPS adalah sebesar $5 \%$ (lima perseratus) dari nilai kontrak;

2) Nilai jaminan pelaksanaan untuk harga penawaran terkoreksi atau di bawah $80 \%$ (delapan puluh perseratus) nilai HPS adalah sebesar 5\% (lima perseratus) dari nilai total HPS; dan

3) Masa berlaku jaminan pelaksanaan sejak tanggal penandatangan kontrak sampai serah terima barang berdasarkan kontrak.

b) Sebelum menandatangani kontrak PPK dan Penyedia Barang/Jasa berkewajiban untuk memeriksa konsep kontrak yang meliputi substansi, bahasa/redaksional, angka, huruf serta membubuhkan paraf pada lembar demi lembar dokumen kontrak.

Berkaitan dengan syarat sahnya suatu kontrak/perjanjian sesuai ketentuan Pasal 1320 Kitab Undang-Undang Hukum Perdata (disingkat KUHPdt), PPK harus memperhatikan hal ini, karena apabila salah satu dari 4 hal tersebut tidak terpenuhi, maka penandatanganan kontrak menjadi tidak sah. Sebelum penandatanganan, PPK harus yakin bahwa yang mewakili penyedia adalah benar-benar direktur atau kuasa direktur yang nama penerima kuasa ada dalam akta atau pejabat yang menurut anggaran dasar perusahaan berhak untuk mengikat perjanjian. Para pihak juga dalam kondisi sah untuk mengikat perjanjian, pokok 
perjanjiannya jelas dan tidak ada hal-hal yang melanggar hukum, baik perdata maupun pidana, dalam isi perjanjian.

\section{Kekuatan Mengikat Surat Penunjukan Penyedia Barang/Jasa Menurut Peraturan Presiden Nomor 16 Tahun 2018}

SPPBJ yang merupakan surat penunjukan yang diberikan kepada penyedia barang/jasa untuk melakukan pekerjaan yang diterbitkan oleh PPK atas penetapan pemenang pengadaan barang/jasa oleh ULP. ${ }^{13}$ SPPBJ berfungsi sebagai tanda bahwa PPK menyetujui penetapan pemenang yang ditetapkan oleh ULP, serta SPPBJ merupakan proses lanjutan dari penetapan pemenang pemilihan penyedia barang/jasa.

Dasar bagi PPK untuk menerbitkan SPPBJ adalah BAHP, sampai pada tahap penerbitan SPPBJ ini proses pemilihan penyedia atau pelelangan yang menjadi tanggung jawab ULP/pejabat pengadaan PPK harus menerbitkan SPPBJ kepada pemenang lelang sebelum masa penawaran yang berlaku habis berakhir berdasarkan pengumuman penetapan lelang. PPK menerbitkan SPPBJ dengan ketentuan sebagai berikut:

a) Tidak ada sanggahan dari peserta lain,

b) Sanggahan dan/atau sanggahan banding tidak terbukti, atau

c) masa sanggah dan/atau sanggah banding telah berakhir.

Batas waktu penerbitan SPPBJ sebagaimana diatur dalam Pasal 85 ayat (5) sampai dengan ayat (8) Perpres No. 54 Tahun 2010 dan telah diubah terakhir dengan Perpres No. 04 Tahun 2015 harus memperhatikan hal berikut:

a) apabila tidak terdapat sanggahan, PPK harus menerbitkan SPPBJ paling lambat 6 (enam) hari kerja setelah pengumuman penetapan pemenang dan segera disampaikan kepada pemenang yang bersangkutan.

b) apabila terdapat sanggahan banding, PPK harus menerbitkan SPPBJ paling lambat 2 (dua) hari kerja setelah semua sanggahan banding dijawab dan segera disampaikan kepada pemenang.

c) apabila terdapat sanggahan tetapi tidak terdapat sanggahan banding, PPK harus menerbitkan SPPBJ paling lambat 6 (enam) hari kerja untuk pelelangan umum dan paling lambat 4 (empat) hari kerja unbtuk pelelangan sederhana dan pemilihan langsung setelah sanggahan dijawab dan segera disampaikan kepada pemenang.

d) Penerbitan SPPBJ untuk seleksi jasa konsultasi harus diterbitkan paling lambat 2 (dua) hari kerja setelah kelompok kerja ULP menyampaikan berita acara hasil seleksi kepada PPK.

Meskipun aturan mengenai batas waktu penerbitan SPPBJ terhadap pemenang lelang telah sedemikian rupa diatur dalam Perpres No. 54 Tahun 2010 dan dirubah terakhir dengan Perpres No. 04 Tahun 2015, namun masih banyak terdapat kemungkinan terjadinya penyimpangan di lapangan. Penyimpangan di lapangan dapat terjadi karena tidak adanya sanksi yang tegas yang dijatuhkan kepada PPK, apabila PPK tidak mematuhi aturan mengenai batas waktu penerbitan SPPBJ. Penyimpangan yang mungkin dapat dilakukan oleh PPK antara lain sebagai berikut: ${ }^{14}$

13 Lembaga Kebijakan Pengadaan Barang dan Jasa Pemerintah, Buku Informasi Membuat Surat Penunjukan Penyedia Barang/Jasa, 2016, h. 32.

14 Sutedi, A. (2014). Aspek Hukum Pengadaan Barang/jasa dan Berbagai Permasalahannya, Jakarta: Sinar Grafika, h. 4. 
a. SPPBJ tidak lengkap. Penunjukan sudah dikeluarkan namun proses sanggahan belum selesai, data pendukung berita acara tentang sanggah jawab belum ada, seolah-olah tidak ada sanggahan. Panitia bekerja secara tertutup, memasuki tahap berikutnya sebelum menyelesaikan proses yang seharusnya mereka selesaikan lebih dulu.

b. SPPBJ yang sengaja ditunda pengeluarannya. Pada hari yang telah ditentukan surat tersebut belum dikeluarkan oleh proyek, ada berbagai alasan untuk mebenarkan langkah tersebut. Dibalik semua itu, adalah perlu adanya uang pelicin.

c. SPPBJ yang dikeluarkan dengan terburu-buru. Dengan dikeluarkannya SPPBJ $a$ quo seolah-olah tidak ada masalah tentang tender yang sedang dilaksanakan. Namun dalam kenyataannya saat tersebut proses sanggah jawab sedang berlangsung sehingga sangat merugikan mitra kerja yang sedang memproses sanggahan tersebut.

d. SPPBJ yang tidak sah. Surat yang belum lengkap sudah beredar atau sudah sampai kepada calon pemenang (dalam hal ini posisinya masih sangat rawan, sebab ada kemungkinan sanggahan benar). Dalam hal ini tanda tangan belum ada, sesungguhnya belum memiliki kekuatan hukum. Digunakan semacam suap kepada pihak tertentu bahwa calon pemenang tersebut memang betul menang. Ada kemungkinan dalam proses akhirnya urutan pertama gugur dan yang mendapat kemenangan adalah yang terendah kedua.

Menyusun SPPBJ, PPK perlu memperhatikan bentuk dan hal-hal yang bersifat teknis administratif sebagai berikut: ${ }^{15}$

a) Kop Surat;

b) Tanggal Penerbitan SPPBJ;

c) Nomor Surat Dan Lampiran;

d) Nama Penyedia Barang/Jasa yang Ditunjuk;

e) Perihal;

f) Paragraf Pembuka;

g) Paragraf Isi;

h) Bagian Pengesahan;

i) Tembusan.

Dalam hal PPK ternyata berpendapaqt lain dari hasil penetapan lelang yang ditetapkan oleh ULP, maka PPK berdasarkan kewenangan yang diperoleh dapat menolak untuk tidak mengeluarkan atau menerbitkan SPPBJ. Terhadap penolakan, PPK memberitahukan perselisihan ini kepada PA/KPA untuk diputuskan. Keputusan PA/KPA diambil dengan berdasarkan pada ketentuan sebagai berikut: ${ }^{16}$

a) Apabila PA/KPA sependapat dengan PPK maka dilakukan evaluasi ulang dengan menyatakan bahwa pelelangan/seleksi yang telah dilakukan gagal;

b) Apabila PA/KPA sependapat dengan ULP, PA/KPA memutuskan penetapan pemenang oleh ULP bersifat final, dan PA/KPA memerintahkan PPK untuk mengeluarkan atau menerbitkan surat SPPBJ.

Seperti telah dikemukakan di atas, bahwa yang menjadi dasar untuk penebitan SPPBJ oleh PPK adalah BAHP. Apabila SPPBJ diterbitkan berarti PPK wajib dan sudah memahami isi BAHP. Memahami isi dari BAHP apalagi berani menolak penetapan ULP berarti PPK

\footnotetext{
15 Lembaga Kebijakan Pengadaan Barang Dan Jasa Pemerintah, Op.Cit, h. 34.

16 Ibid., h. 32.
} 
wajib memiliki pengetahuan terhadap proses pelelangan/seleksi yang telah dilakukan oleh ULP. Dengaan demikian, maka selain kemampuan manajerial yang wajib dimiliki oleh PPK, PPK juga wajib mengetahui proses pengadaan barang/jasa secara utuh dan lengkap pada masing-masing pentahapannya serta memahami hal-hal apa saja yang telah dievaluasi oleh panitia serta kelemahan-kelemahannya.

Inilah alasannya mengapa setiap PPK wajib memiliki sertifikasi pengadaan barang/jasa. Sertifikasi bukan hanya merupakan selembar kertas tanpaartinya, melainkan PPK wajib mengetahui proses pengadaan barang/jasa secara detail agar dapat menjalankan fungsi parameter terhadap evaluasi kinerja panitia dan mampu untuk menolak usulan pemenang dari panitia.

Pentingnya kemampuan manajerial PPK dan pengetahuan yang detail terhadap proses pengadaan barang/jasa yang dimiliki PPK, oleh sebab itu, agar seseorang dapat diangkat sebagai PPK harus memenuhi syarat sebagai berikut: ${ }^{17}$

a) Memiliki Integritas;

b) Memiliki disiplin tinggi;

c) Memiliki tanggung jawab dan kualifikasi teknis serta manajerial untuk melaksanakan tugas;

d) Mampu mengambil keputusan, bertindak tegas dan memiliki keteladanan dalam sikap perilaku serta tidak pernah terlibat KKN;

e) Menandatangani pakta integritas;

f) Tidak menjabat sebagai pejabat penandatanagn surat perintah membayar (PPSPM) atau bendahara;

g) Memiliki sertifikat keahlian barang dan jasa.

Apabila penyedia barang/jasa yang telah ditunjuk dalam SPPBJ, namun ternyata penyedia tidak menjalankan atau melaksanakan pekerjaan sesuai dengan isi SPPBJ, maka terhadap penyedia barang/jasa yang telah ditunjuk dapat dikenakan sanksi sebagaimana diatur dalam ketentuan Pasal 85 ayat (1) sampai dengan ayat (4) Pepres No. 54 Tahun 2010 sebagaimana telah diubah terakhir dengan Perpres 04 Tahun 2015 yanng secara garis besa mengatur antara lain sebagai berikut:

a) apabila penyedia barang/jasa telah menerima SPPBJ mengundurkan diri dan masa penawarannya masih berlaku, maka pengunduran diri penyedia barang/jasa hanya dapat dilakukan berdasarkan alasan yang dapat diterima secara obyektif oleh PPK.

b) Pengunduran diri oleh penyedia barang/jasa, dilakukan dengan ketentuan bahwa jaminan penawaran peserta lelang yang bersangkutan dicairkan dan disetorkan pada kas negara atau kas daerah.

c) apabila penyedia barang/jasa yang ditunjuk sebagai pelaksana pekerjaan mengundurkan diri dengan alasan yang tidak dapat diterima secara obyektif oleh PPK dan masa penawarannya masih berlaku, maka:

1) Jaminan penawaran penyedia barang/jasa yang bersangkutan dicairkan dan disetorkan kepada kas negara atau kas daerah.

2) Penyedia barang/jasa dikenakan sanksi berupa larangan untuk mengikuti kegiatan pengadaan barang/jasa pada instansi pemerintah selama 2 (dua) tahun.

Berdasarkan pengaturan ketentuan di atas, terlihat bahwa dalam Perpres No. 54 Tahun 2010 sebagaimana perubahan terakhir Perpres No. 04 Tahun 2015 masih mempunyai kekurangan, khususnnya mengenai penerbitan SPPBJ. Padahal, hingga pada kontrak resmi

17 Pasal 12 ayat (2) Perpres No. 54 Tahun 2010 perubahan terakhir Perpres No. 04 Tahun 2015. 
disiapkan dan diberlakukan, SPPBJ akan berlaku sebagai kontrak pengikat. ${ }^{18}$ Atau dengan lain perkataan bahwa kedudukan SPPBJ dalam suatu kontrak pengadaan barang/jasa pemerintah adalah sebagai kontrak pengikat.

Sehingga mengikat maupun tidak mengikatnya suatu kontrak pengadaan barang/jasa terhadap para pihak yang membuat kontrak dimaksud tergantung pula kepada sah atau tidak sahnya kontrak yang dibuat oleh para pihak. Pasal 1338 KUHPdt menyatakan bahwa: "Semua perjanjian yang dibuat secara sah berlaku sebagai undang-undangbagi mereka yang membuatnya". Pengaturan Pasal 1338 KUHPdt jelas akan mengikat para pihak dalam kontrak pengadaan barang/jasa.

Kontrak baku memiliki dimensi mata uang yang mempunyai dua sisi, sisi yang satu membolehkan bahkan mungkin sekali bahwa kontrak baku menjadi tidak sah dan sisi yang lainnya kontrak baku dapat dikatakan legal dan keberadaannya sangat dibutuh ${ }^{19}$. Sah atau tidak sahnya suatu kontrak pengadaan barang/jasa dapat dipastikan dengan pengujiannya menggunakan instrumen hukum kontrak yang terimpelementasi dalam wujud syarat-syarat sahnya suatu kontrak (termasuk kontrak pengadaan barang/jasa), sebagaimana diatur secara terstruktu dan sistematis dalam buku III KUHPdt. ${ }^{20}$ Menurut Y. Sogar Simamora ${ }^{21}$ : "Penerbitan SPPBJ oleh PPK menandakan adanya penerimaan/akseptasi atas penawaran yang diajukan oleh calon penyedia barang/jasa. Terjadinya akseptasi menandai terjadinya kesepakatan."

Hak dan kewajiban para pihak dalam kontrak pengadaan barang/jasa efektif baru dapat diberlakukan setelah adanya atau terbentuk kesepakatan. SPPBJ yang diterbitkan oleh PPK dalam suatu proses pengadaan barang/jasa baru mempunyai kekuatan hukum yang mengikat, dalam arti setelah SPPBJ diterbitkan harus ditindaklanjuti dengan proses penandatanganan kontrak pengadaan barang/jasa. Dalam teorinya, setelah dikeluarkannya SPPBJ oleh PPK, PPK tidak dapat lagi membatalkan secara sepihak kesepakatan atau dalam kesepakatan terwujudkan dengan SPPBJ yang telah dikeluarkan.

Tetapi dalam hal alasan yang dapat diterima, maka akan terdapat pengecualian terhadap pembatalan SPPBJ oleh PPK. Artinya bahwa jika dalam pelaksanaan proses pengadaan barang/jasa, setelah penerbitan SPPBJ oleh PPK, terdapat keadaan yang mengharuskan dilakukannya pembatalan terhadap SPPBJ yang telah dikeluarkan, PPK dapat melakukan pembatalan terhadap SPPBJ yang telah dikeluarkan. Keadaan yang dikecualikan dapat dicontohkan dalam masa pandemi Covid-19 saat ini, di mana terjadi refocusing dan relokasi terhadap kegiatan dan anggaran oleh pemerintah untuk mengatasi, menekan, dan mencegah penyebaran pandemi Covid-19 di Indonesia.

SPPBJ pada prinsipnya merupakan dasar bagi PPK dan penyedia barang/jasa untuk melakukan pekerjaan yang diawali dalam satu bukti perjanjian, SPPBJ juga dapat berfungsi sebagai jaminan atas kepastian bagi penyedia barang/jasa dalam memperoleh suatu pekerjaan pengadaaqn barang/jasa. Berdasarkan hal itu, maka pengaturan waktu penerbitan SPPBJ harus dilakukan dengan secepat mungkin, pada saat suatu proses pemilihan telah dinyatakan selesai oleh Panitia. SPPBJ juga dapat dipergunakan oleh penyedia barang/jasa sebagai dasar dalam melakukan pengurusan jaminan pelaksanaan atas pengadaan

18 Buku Informasi Membuat Surat Penunjukan Penyedia Barang/ Jasa, Op Cit, h.4.

19 Adityo, R. D. (2016), "Efektifitas Kontrak Baku dalam Mobilitas Bisnis (Perspektif Hukum Progresif)", Mahkamah, 1 (1): 111-119, h. 119.

20 Syaifuddin, M. (2012). Hukum Kontrak (Memahami Kontrak Dalam Perspektif Filsafat, Teori, Dogmatik dan Praktik Hukum), Bandung: Mandar Maju, h. 110.

21 Simamora, Y. S. Op.Cit, h.174. 
barang/jasa, kecuali terhadap pekerjaan jasa konsultansi, karena pada dasarnya pekerjaan jasa konsultasi yang tidak memerlukan jaminan pelaksanaan.

Hal ini dikarenakan sebelum kontrak pengadaan barang/jasa ditandatangani, penyedia barang/jasa harus sudah dapat menyerahkan jaminan pelaksanaan. Jaminan pelaksaan tersebut akan berfungsi sebagai jaminan bagi PPK jika terdapat wanprestasi yang dilakukan oleh penyedia barang/jasa setelah penandatanganan kontrak pengadaan barang/jasa. Selain itu, jaminan tersebut akan menjadi dasar bagi PPK dalam mencairkan jaminan pelaksanaan tersebut.

\section{PE N T U P}

Berdasarkan uraian yang disebutkan di atas, dapat disimpulkan bahwa setelah proses lelang sampai dengan ditetapkannya pemenang lelang dan penerbitan SPPBJ oleh PPK merupakan suatu rangkaian awal pengadaan barang/jasa. Setelah PPK menebitkan SPPBJ, maka sampai dengan kontrak resmi disiapkan dan diberlakukan, SPPBJ akan berlaku sebagai kontrak pengikat. Disini kedudukan SPPBJ sangat diperlukan karena dapat saja kontrak dibatalkan atau dialihkan karena adanya refocusing kegiatan dan relokasi anggaran akibat dampak pandemi Covid-19 seperti saat ini. Perlu ada pengaturan yang lebih ketat dalam proses penerbitan SPPBJ untuk mengatasi penyimpangan-penyimpangan yang terjadi oleh PPK.

\section{DAFTAR PUSTAKA}

\section{Jurnal}

[1] Adityo, R. D. (2016). Efektifitas Kontrak Baku dalam Mobilitas Bisnis (Perspektif Hukum Progresif). Mahkamah, 1 (1): 111-119.

[2] Butarbutar, R. (2015). Pertanggungjawaban Korporasi Dalam Tindak Pidana Korupsi Pengadaan Barang dan Jasa Pemerintah di Bidang Konstruksi. Jurnal Penelitian Hukum Legalitas, 9 (1): 51-55.

[3] Fajarini, D. P. (2019). Subkontrak Dalam Pengadaan Barang/Jasa Pemerintah. Mimbar Keadilan, 12 (1): 67-84.

[4] Listiyanto, A. (2012). Pembaharuan Regulasi Pengadaan Barang dan Jasa Pemerintah. Rechts Vinding, 1 (1): 113-134.

[5] Manery, B. D. (2017). Makna Dan Fungsi Itikad Baik Dalam Kontrak Kerja Konstruksi. SASI, 23 (2): 136-148.

[6] Muskibah \& Hidayah, L. N. (2020). Penerapan Prinsip Kebebasan Berkontrak dalam Kontrak Standar Pengadaan Barang dan Jasa Pemerintah di Indonesia. Refleksi Hukum, 4 (2): 175-194, DOI: https://doi.org/10.24246/jrh.2020.v4.i2.p175-194.

[7] Pane, M. D. (2017). Aspek Hukum Pengadaan Barang Dan Jasa Pemerintah Suatu Tinjauan Yuridis Peraturan Pengadaan Barang Dan Jasa Pemerintah. Jurnal Media Hukum, 24 (2): 174-155, DOI: 10.18196/ jmh.2017.0090.147- 155.

[8] Putra, K. D. H. (2019). Penyelesaian Sengketa Kontrak dalam Pengadaan Barang/Jasa Pemerintah. Jurist-Diction, 2 (4): 1303-1318.

[9] Kuahaty, S. S. (2011). Pemerintah Sebagai Subjek Hukum Perdata Dalam Kontrak Pengadaan Barang Atau Jasa. SASI, 17 (3): 53-58 , h. 53.

[10] Sanjaya, D., Siregar, R., \& Windha. (2013). Analisis Yuridis Pengadaan Barang/Jasa yang Dilakukan Dinas Pendidikan Kota Tanjungbalai Ditinjau dari Peraturan Presiden Nomor 54 Tahun 2010 Tentang Pengadaan Barang/Jasa Pemerintah. TRANSPARENCY Jurnal Hukum Ekonomi, 1 (2): 1-7. 
[11] Situmeang, I. S. (2017). Pembatalan Surat Penunjukan Penyedia Barang dan Jasa dalam Kontrak Pengadaan Barang dan Jasa Pemerintah. DiH Jurnal Ilmu Hukum, 13 (26): 217-230.

\section{Buku}

[12] Ramli, S. (2014). Bacaan Wajib Sertifikasi Ahli Pengadan Barang/Jasa Pemerintah, Jakarta: Visimedia.

[13] Syaifuddin, M. (2012). Hukum Kontrak (Memahami Kontrak Dalam Perspektif Filsafat, Teori, Dogmatik dan Praktik Hukum), Bandung: Mandar Maju.

[14] Simamora, Y. S. (2013). Hukum Kontrak (Kontrak Pengadaan barang dan Jasa Pemerintah di Indonesia), Surabaya: Laksbang.

[15] Sutedi, A. (2014). Aspek Hukum Pengadaan Barang/jasa dan Berbagai Permasalahannya, Jakarta: Sinar Grafika.

\section{Lain-Lain}

[16] Lembaga Kebijakan Pengadaan Barang dan Jasa Pemerintah, Buku Informasi Membuat Surat Penunjukan Penyedia Barang/Jasa, 2016. 